\title{
Virus-vector nematodes in cereals and fruit crops in Spain
}

\author{
by M. ARIAS and M. F. ANDRÉS \\ Instituto de Edafología y Biología Vegetal, Serrano, 115 duplicado, 28006 Madrid (Spain)
}

\begin{abstract}
Studies on nepoviruses and tobraviruses, and their relationships with their associated vector nematodes, are scarce in Spain. However, virus disease symptoms have often been detected and their nematode vectors are widespread in Peninsular Spain. Nepovirus vector nematodes (Longidorus attenuatus, L. coespiticola, L. elongatus, L. macrosoma, Xiphinema coxi, X. diversicaudatum, $X$. index, $X$. italiae, $X$. pseudocoxi and $X$. vuittenezi) have been found associated with fruit and cereal crops. All are also widespread in other crops and uncultivated areas, together with $X$. rivesi, which has not yet been found associated with fruit and cereal crops in Spain. Tobravirus vectors have been less studied in Spain. Of the five recorded species, Paratrichodorus minor and Trichodorus primitivus are present on maize and wheat respectively. The geographical and host distribution of these nematodes are given and their ecological characteristics are discussed.
\end{abstract}

\section{Introduction}

Virus vector nematodes, especially Longidorids, have been rather well studied in Spain with respect to: distribution in different areas and crops (Arias et al., 1985, 1986a; Bello et al., 1986; Navas \& Arias, 1986; Navas et al., 1988); taxonomy and morphology (Andrés \& Arias, 1987, 1988a; Arias, 1978; Arias \& Roca, 1986; Arias et al., 1986b, 1987; Rey et al., 1988; Roca \& Arias, 1986). Some work also exists on biology (Andrés \& Arias, 1988b), pathogenicity (Andrés \& Arias, 1985, 1988a) and ultrastructure (Lopez-Abella et al., 1964, 1966, 1967; Andrés et al., 1988, 1989).

As regards nepoviruses, some papers have dealt with grapevine fanleaf nepovirus (Peña Iglesias \& Ayuso, 1971; Peña Iglesias et al., 1978; Fresno et al., 1978; Romero et al., 1978), artichoke degeneration virus (Romero et al., 1985) and fruit trees crops (Camarasa et al., 1987). There are only two papers on nematode-virus disease relationships (Alfaro Garcia, 1971; Fijo \& Arias, 1976) and there is no joint work between virologists and nematologists, though some associations have been detected in the field.

The aim of this work was, therefore, to compile the information available on this subject in Spain and to discuss the problems that these nematodes could represent for cereals and fruit crops, the importance of such crops as refuges and sources of these pathogens, and their ecology and distribution. Joint studies between nematologists and virologists are needed on the epidemiology of these diseases as a basis for preventing their spread and the introduction of new viruses and/or strains.

\section{Virus-vector nematodes in cereai growing areas}

Brome mosaic bromovirus (BMV) is the only virus reported to be transmitted in cereals by nematodes, Xiphinema paraelongatum and X. coxi (Bancroft, 1970). It causes mosaic on barley, wheat, oats, rye and necrosis on maize, and probably has the widest range of grass hosts of any mechanically transmissible virus. It has been reported in USA, South Africa, Germany, Finland and Russia, but not yet in Spain (Jordá \& Osca, 1987). However, X. coxi europaeum and $X$. pseudocoxi, components of the $X$. coxi complex (Sturhan, 1985), have been reported at 11 
localities in the Región Central, and at one biotope in La Rioja and at seven points in the Región Central respectively, but have not yet been found on cereal crops.

Another nematode of this family, Longidorus belloi, recently described and not yet demonstrated as a virus vector, has been found in cereal growing areas, causing root tip galls in wheat, barley, lentil, vetch and rye-grass (Andrés \& Arias, 1988c).

Besides, L. elongatus has been found on rye and wheat, $X$. diversicaudatum on oats and wheat, $X$. index on maize, and $X$. italiae on barley, oats and wheat. All these nematodes are vectors of different nepoviruses in other crops. Among tobravirus vectors, Paratrichodorus minor has been reported causing damage on maize (Del Moral \& Martinez-Aljama, 1985) and P. hispanus has recently been described on wheat (Roca \& Arias, 1986). Though none of these nematodes are vectors of any virus in cereal crops, they could use them as refuges.

\section{Virus-vector nematodes in fruit crops}

Some 16 nepoviruses have been reported on fruit crops in Europe and America, transmitted by seven species of Longidorus, five of Xiphinema and one of Paralongidorus. Only cherry leaf roll nepovirus (CLRV) has been detected in Spain, on almond, hazel and walnut, and only recently (Camarasa et al., 1987). However, eight nepovirus vectors appear widespread on different host plants, five of them in association with fruit crops. Table 1 shows the virus-vector nematodes which occur on fruit trees in Spain, as well as the viruses which they have been reported to transmit in other countries.

Table 1. Nematode-borne virus diseases in Spanish fruit crops

Viroses transmises par les nématodes dans les cultures fruitières en Espagne

\begin{tabular}{|c|c|c|c|}
\hline Nematode & Nepovirus & $\begin{array}{l}\text { Host plants in which virus } \\
\text { transmission has been proved }\end{array}$ & $\begin{array}{l}\text { Spanish fruit crops } \\
\text { concerned }\end{array}$ \\
\hline L. attenuatus & $\begin{array}{l}\text { TBRV English strain } \\
\text { (tomato black ringspot) }\end{array}$ & pear & $\begin{array}{l}\text { apple, fig, peach, plum, } \\
\text { quince and medlar }\end{array}$ \\
\hline L. coespiticola & AMV (arabis mosaic) & cherry, plum, strawberry & $\begin{array}{l}\text { almond, apple, fig, pear, } \\
\text { peach, plum, } \\
\text { strawberry and walnut }\end{array}$ \\
\hline \multirow[t]{4}{*}{ L. macrosoma } & $\begin{array}{l}\text { CCRV (cherry chlorotic } \\
\text { ringspot) }\end{array}$ & cherry & fig \\
\hline & $\begin{array}{l}\text { PNRV (prunus necrotic } \\
\text { ringspot) }\end{array}$ & prunus & \\
\hline & $\begin{array}{l}\text { RRSV cherry strain } \\
\text { (raspberry ringspot) }\end{array}$ & cherry, plum & \\
\hline & RRSV English strain & $\begin{array}{l}\text { mulberry, pear, raspberry } \\
\text { and strawberry }\end{array}$ & \\
\hline \multirow[t]{6}{*}{$X$. diversicaudatum } & AMV & cherry, plum, strawberry & $\begin{array}{l}\text { cherry, sweet cherry, fig, } \\
\text { hazel and plum }\end{array}$ \\
\hline & CCRV & cherry & \\
\hline & CLRV (cherry leaf roll) & cherry, blackberry, plum & \\
\hline & RMV (rosette mosaic) & peach, pear & \\
\hline & RRSV English strain & $\begin{array}{l}\text { cherry, mulberry, raspberry, } \\
\text { peach, plum }\end{array}$ & \\
\hline & SRV (strawberry ringspot) & peach & \\
\hline$X$. vuittenezi & CLRV (cherry leaf roll) & cherry, blackberry, plum & apricot and pear \\
\hline
\end{tabular}


Vector species which have not been found in fruit crops in Spain are: L. elongatus, vector of CLRV and raspberry ringspot nepovirus; $X$. coxi complex, vector of arabis mosaic nepovirus (AMV) and strawberry latent ringspot nepovirus (SLRV); $X$. rivesi, vector of tomato ringspot nepovirus (TomRSV) on different fruit trees and small-fruit crops. These nematodes have, however, been reported on many other host plants.

On the other hand, Arias et al. (1985) have reported the presence on fruit trees of nematodes which transmit viruses to other crops: $X$. index (on apricot, fig, medlar and peach); $X$. italiae (on almond, apricot, cherry, hazel, mulberry, peach, pomegranate and walnut). In addition, Trichodorus spp., which are vectors of tobacco rattle tobravirus and pea early browning tobravirus, have been found on cherry, fig and pear.

\section{Distribution and ecology}

The geographical distribution of these species in Spain is illustrated in Figs 1-4. Studies carried out in Spain on the influence of environmental factors on species of the family Longidoridae show that their occurrence is greatly influenced by vegetation, climate and soil structure. So, we can distinguish two groups according to their distribution, one formed by L.attenuatus, L. belloi, $L$. elongatus and L. macrosoma, appearing in Mediterranean environments with a potential vegetation of evergreen oaks (Quercus ilex) and a semi-arid climate, and the other by $L$. coespiticola, $X$. diversicaudatum, $X$. vuittenezi and $X$. coxi complex, preferring atlantic environments with deciduous oaks and subhumid to humid climate, which is in agreement with their distribution in Europe and with the observations by Bello et al. (1986).

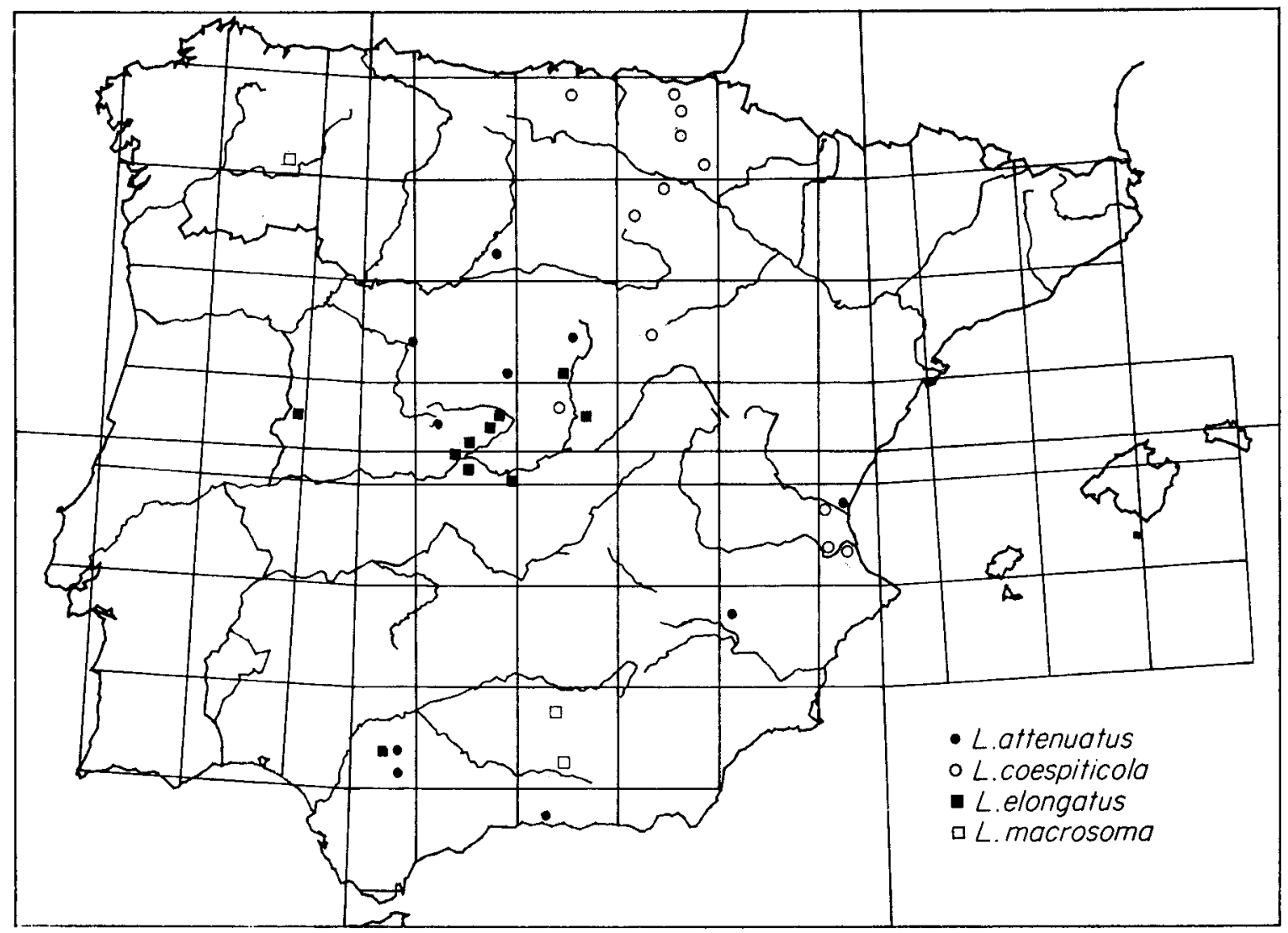

Fig. 1. Geographical distribution in Spain of Longidorus spp. known elsewhere as virus vectors on fruit crops.

Répartition géographique en Espagne des espèces de Longidorus reconnues ailleurs comme vecteurs de virus des arbres fruitiers. 


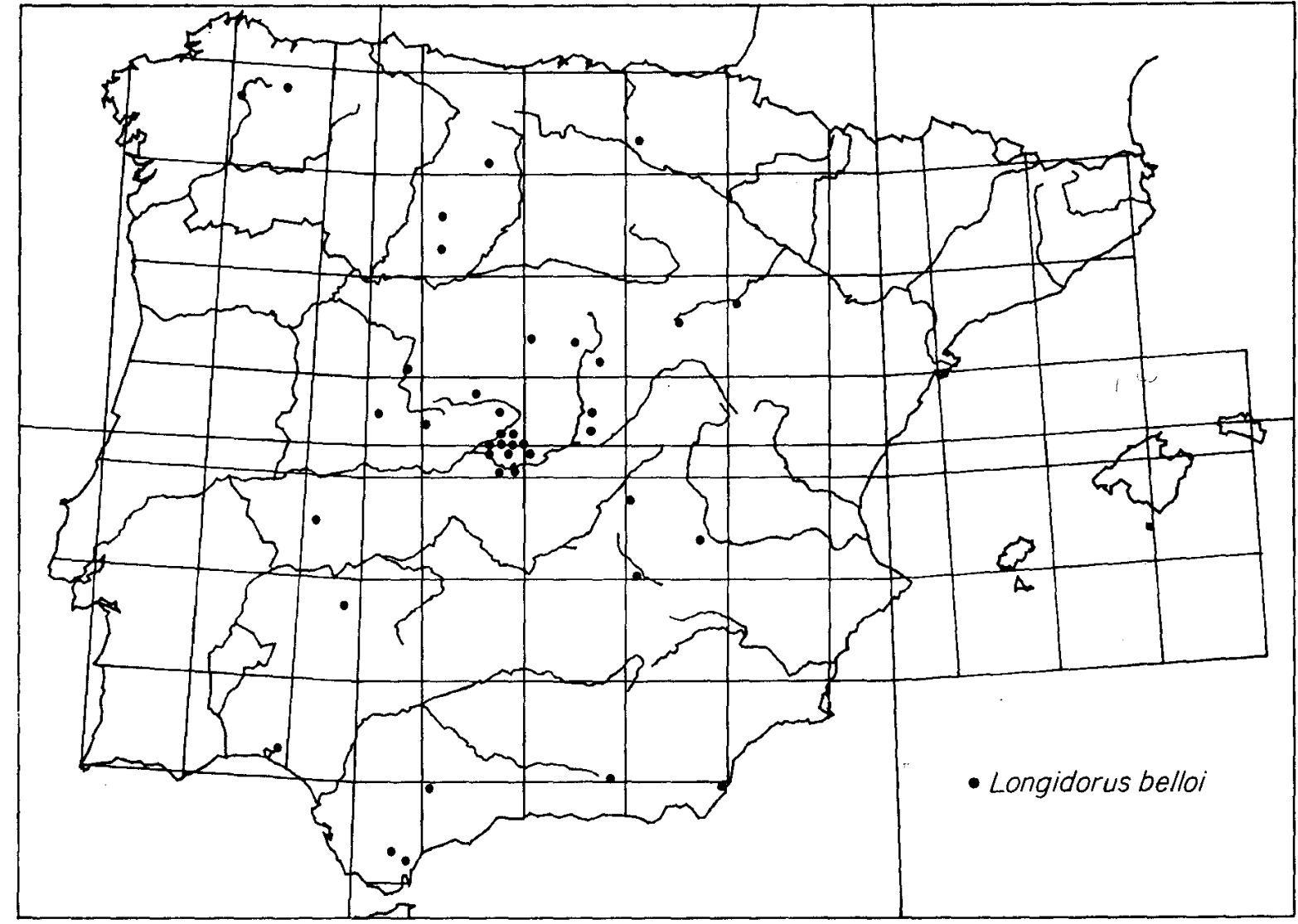

Fig. 2. Geographical distribution in Spain of Longidorus belloi.

Répartition géographique en Espagne de L. belloi.

L. attenuatus has appeared mainly in the south-western quadrant of the peninsula with some records in the Región Central and the Mediterranean coast, on cultivated land, mainly fruit crops, and on uncultivated areas on siliceous soil. $L$. belloi, previously reported as $L$. profundorum (Andrés \& Bello, 1984; Arias et al., 1985) is the most frequent and widespread species in the genus and occurs mainly in the Region Central in different crops, especially cereals, and also in uncultivated zones, in clay soils, often in deeper horizons (15-40 cm depth). $L$. elongatus is mainly distributed in the Región Central in uncultivated areas, while L. macrosoma also occurs in uncultivated areas but is much more common in crops, especially fruit crops and vineyards.

L. coespiticola has appeared in the northern central area of continental Spain and at some isolated points on the Mediterranean coast, in fruit crops and uncultivated zones with calcareous soils. $X$. coxi complex ( $X$. coxi europaeum and $X$. pseudocoxi) has a distribution restricted to the Región Central, with one isolated record in La Rioja, associated with sandy-loam soils with 3$7 \%$ of organic matter and $\mathrm{pH} 6$. It prefers uncultivated woodlands and pasturelands, though $X$. pseudocoxi has been found once in association with fruit trees crops and vineyards. $X$. diversicaudatum is rather widespread in the northern central area of Spain, can be considered typical of uncultivated soils with high contents of organic matter, but is also frequent in fruit crops and there are a few records in cereal areas; it is predominant in siliceous soils with coarse particles and is found in the higher altitudes, depending on climate, potential vegetation and crops. The Región Central can be considered the southern limit of its distribution (Navas et al., 1988). $X$. vuittenez $i$ is not very frequent but has appeared especially in the northern-central area of Spain in uncultivated soils and fruit crops (Navas et al., 1988). Finally, X. rivesi has been found at one spot in the Región Central on grapevine and one in the south causing damage to roses. 


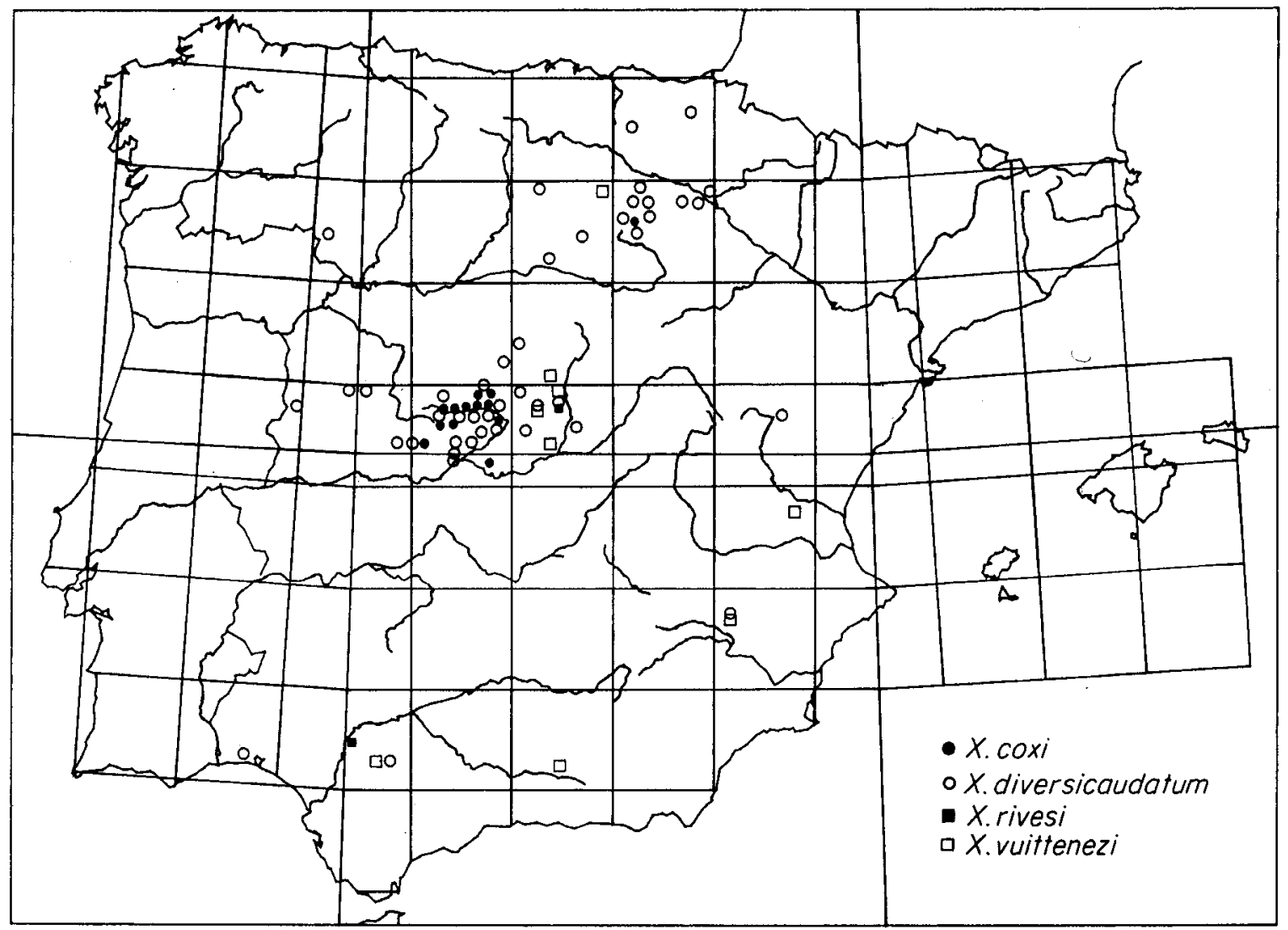

Fig. 3. Geographical distribution in Spain of Xiphinema spp. known elsewhere as virus vectors on fruit crops and cereals.

Répartition géographique en Espagne des espèces de Xiphinema reconnues ailleurs comme vecteurs de virus des arbres fruitiers et des céreales.

Tobravirus vectors, Trichodorus and Paratrichodorus spp., have been less studied in Spain. There are records of $P$. minor on maize and potatoes, $P$. hispanus on wheat, $P$. cf. acutus on Quercus pyrenaica, Trichodorus primitivus on Ulmus sp., Trichodorus $\mathrm{cf}$. cedarus on Quercus pyrenaica and Trichodorus spp. on cherry, fig, pear, uncultivated woodlands and vegetable crops such as pea and potatoes.

\section{Conclusions}

Studies on nepoviruses and tobraviruses are scarce in Spain in spite of the fact that their nematode vectors are well represented in cultivated as well as in uncultivated soils. CLRV is the only nepovirus detected on fruit trees, no nematode-transmitted virus has been found on cereals and no tobraviruses have been reported.

Relationships between nematode vectors and the viruses they transmit have not been investigated in Spain in spite of the number of virus-vector species reported with this capability in fruit crops and cereals in Spain. Longidorid nepovirus vectors could have important economic influences on these crops, while tobravirus vectors could use some of these crops, especially cereals or weeds in fruit crops, as refuges.

Environmental factors have a notable influence on virus-vector nematode distribution. In Spain these nematodes can be classified into two groups according to their distribution areas, one Mediterranean (L. attenuatus, L. belloi, L. elongatus and L. macrosoma) and the other Atlantic or Continental ( $L$. coespiticola, $X$. diversicaudatum, $X$. vuittenezi and $X$. coxi complex).

Joint studies by nematologists and virologists on the distribution and biology of these 


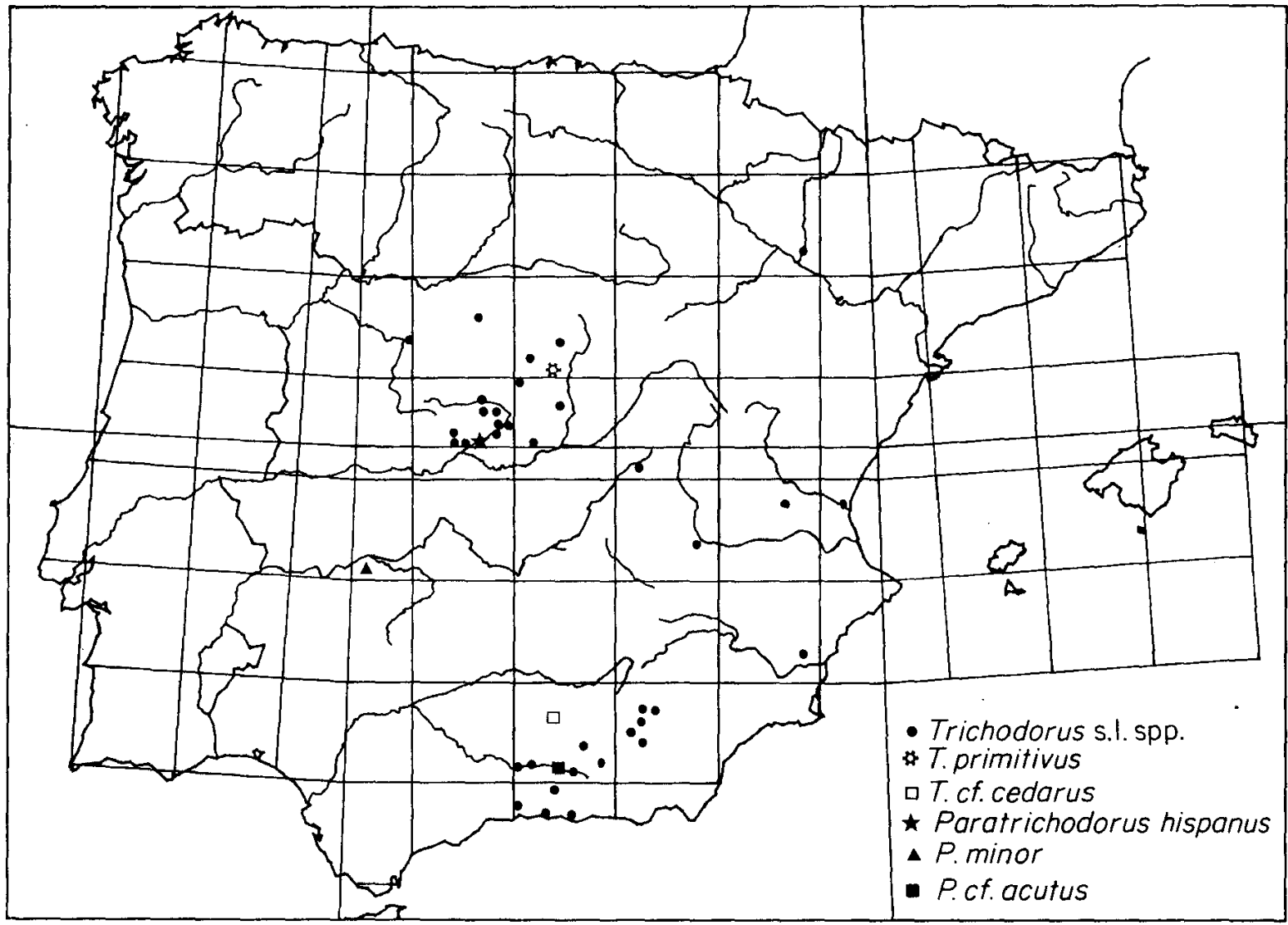

Fig. 4. Geographical distribution in Spain of Paratrichodorus spp. and Trichodorus spp. Répartition géographique en Espagne des espèces de Paratrichodorus et de Trochodorus.

nematodes in relation to virus diseases, as well as on host/parasite relationships and virus transmission, are needed to understand the pathological and resistance phenomena generated by the direct action of the pathogens of the host plants.

Studies on the transmission capability of Spanish species for alien virus strains will be necessary to know the potential of new viruses or strains which could be introduced into our crops, as well as the role of cereal crops and weeds of fruit crops as tobravirus-vector refuges. They are needed to prevent the spread of such diseases and the introduction of new strains and to find alternative solutions to the use of chemical soils sterilizants for the control of their vectors.

\section{Acknowledgements}

The authors are indented to Prof. Bello for his suggestions and to Mrs Robles for her assistance.

\section{Nématodes vecteurs de virus sur cultures céréalières et fruitières en Espagne}

Il manque, en Espagne, des études approfondies sur les népovirus et les tobravirus, et leurs associations avec des nématodes vecteurs. Toutefois, des symptômes probablement attribuables à ces virus sont fréquemment constatés et les vecteurs sont largement disséminés en Espagne continentale. Plusieurs vecteurs de népovirus (Longidorus attenuatus, L. coespiticola, L. elongatus, L. macrosoma, Xiphinema coxi, $X$. diversicaudatum, $X$. index, $X$. italiae, $X$. pseudocoxi et $X$. vuittenezi) ont été détectés en association avec des cultures fruitières et céréalières. Ils sont fréquents sur d'autres cultures, et dans les zones non cultivées, de même que $X$. rivesi jusqu'ici non trouvé sur arbres fruitiers ou céréales en Espagne. Les vecteurs de tobravirus sont moins bien connus en Espagne. Parmi les cinq espèces présentes, Paratrichodorus minor et Trichodorus 
primitivus sont présents sur maïs et sur blé, respectivement. Des résultats sont présentés sur la distribution géographique et les plantes-hôtes de ces nématodes, ainsi que sur leur écologie.

\section{Вирусоносные нематоды на злаковых и фруктовых культурах в Испании}

Исследования неповирусов и тобравирусов и их взаимосвязи с соотвествующими нематодами-переносчиками в Испании до настоящего времени почти не проводились. При этом, однако, симптомы вирусного заболевания очень часть обнаруживались и переносящие их нематоды широко распространены на Пиренейском полуострове. Нематоды-переносчики неповирусов (Longidorus attenuatus, L. coespiticola, L. elongatus, L. macrosoma, Xiphinema coxi, $X$. diversicaudatum, $X$. index, $X$. italiae, $X$. pseudocoxi и $X$. vuittenezi ) были найдены в сочетании с фруктовыми и злаковыми культурами. Все они также широко распространены на других культурах и невозделываемых площадях, вместе с X. rivesi, который в настоящее время еще не был найден в сочетании с фруктовыми и злаковыми культурами в Испании. Переносчики тобравирусов в Испании изучались в меньшей степени. Из пяти зарегистрированных видов, Paratrichodorus minor и Trichodorus primitivus присутствуют на кукурузе и пшенице, соответственно. Распределение этих нематод по географическим зонам и растениям-хозяевам приводится в настоящей статье с указанием их соответствующих экологических характеристик.

\section{References}

Alfaro Garcia, A. (1971) [Presence in Spain of grapevine fanleaf virus]. Anales del Instituto Nacional de Investigaciones Agrarias, Protección Vegetal 1, 71-80 (in Spanish).

ANDRÉs, M.F. \& ARIAS, M. (1985) [Pathogenicity of the ectoparasitic nematode Longidorus profundorum on cereals and legumes]. Boletin del Servicio de Defensa contra Plagas e Inspección Fitopatológica 11, 37-42 (in Spanish).

ANDRÉs, M.F. \& ARIAS, M. (1987) A new species of Longidorus associated with forest soils and notes on $L$. congoensis and L. intermedius new records for Spain. Nematologica 33 386-392.

ANDrés, M.F. \& ARIAS, M. (1988a) Longidorus belloi n.sp. from Spain. Revue de Nématologie 11, 415-421.

ANDRÉs, M.F. \& ARIAS, M. (1988b) Observation on the population dynamics of Longidorous belloi in cereal fields of the Central Region (Spain). Nematologia Mediterranea 17, 35-37.

ANDRÉs, M.F. \& BELLO, A. (1984) [Effect of soil and cultivation methods on Longidorus profundorum, a plant-parasitic nematode of interest in the cereal-growing areas of the Región Central]. Anales de Edafologia y Agrobiologia 43, 727-723 (in Spanish).

ANDRES, M.F., ARIAS, M. \& BlEVE-ZACHeo, T. (1988) Cereal and leguminous host response to Longidorus belloi feeding. Nematologia Mediterranea 16, 201-204.

ANDrÉs, M.F., Bleve-ZaCheo, T. \& ARias, M. (1989) Ultrastructure of cereal and leguminous roots parasitized by Longidorus belloi. Revue de Nématologie (in press).

ARIAS, M. (1978) Abnormal female gonad in Xiphinema diversicaudatum. Nematologia Mediterranea 6, 231233.

ARIAS, M. \& RoCA, F. (1986) Trichodorus castellanensis, a junior synonym of Trichodorus primitivus. Nematologia Mediterranea 14, 279-281.

ARIAS, M., NAVAS, A. \& BELLO, A. (1985) [Ectoparasitic virus-vector nematodes of the family Longidoridae: distribution in continental Spain]. Boletín del Servicio de Defensa contra Plagas e Inspección Fitopatológica 11, 275-337 (in Spanish).

Arias, M., Navas, A. \& Bello, A. (1986a) Analysis of the geographical distribution of Xiphinema diversicaudatum and $X$. pachtaicum in relation to environmental factors in Spain. Nematologia Mediterranea 14, 7-13.

ARIAS, M., ANDrÉs, M.F. \& Navas, A. (1986b) Longidorus carpetanensis sp.n. and L. unedoi sp.n. from Spain. Revue de Nématologie 9, 101-106.

Arias, M., NAVAS, A. \& ANDRÉs, M.F. (1987) Studies on morphometrics, distribution and ecology of the Xiphinema coxi complex in Spain. Revue de Nématologie 10, 377-380.

Bancroft, J.B. (1970) Brome mosaic virus. CMI/AAB Descriptions of Plant Viruses no. 3. AAB, Wellesbourne (GB) (see also no. 180, a revision of no. 3 by L.C. Lane).

Bello, A., Topham, P.B., Alphey, T.J.W. \& Dale, A. (1986) Biogeographical classification of some plantparasitic nematode species groups in Spain. Nematologia Mediterranea 14, 41-54. 
Camarasa, E., Cambra, M., Llacer, G. \& Aramburu, J. (1987) Virus infecting almond, hazelnut and walnut trees in some Mediterranean regions of Spain. In Proceedings of the 7th Congress of the Mediterranean Phytopathological Union, pp. 192-193. Centro de Información y Documentación Agraria, Sevilla (ES).

Del Moral, J. \& Martinez Aljama, F. (1985) [Biology and control of plant-parasitic nematodes on maize]. Anales del Instituto Nacional de Investigaciones Agrarias, Agricola 28, 73-79 (in Spanish).

Fijo, M.A. \& ARIAs, M. (1976) La dégénérescence infectieuse dans les vignobles de Jerez (Espagne). Agriculturae Conspectus Scientificus 39, 575-585.

Fresno, J., Peña-Iglesias, A., Castro, S. \& Rey, M.C. (1978) [Ultrastructure of Chenopodium quinoa and Cucumis sativus infected by grapevine fanleaf virus after preliminary treatment to eliminate ribosomes]. Monografias INIA 18, 97-101 (in Spanish).

JoRDÁ, M.C. \& OsCA, J.M. (1987) [Cereal virus diseases]. El Campo. Boletín de Información Agraria 106, 7880 (in Spanish).

LopeZ-Abella, D., Jimenez-Millan, F. \& MARIN, M. (1964) [Submicroscopic structures in Xiphinema and Pelodera]. Boletín de la Real Sociedad Española de Historia Natural, Seccion Biología 62, $379-384$ (in Spanish).

Lopez-Abella, D., Jimenez-Millan, F. \& Garcia Hidalgo, F. (1966) [Submicroscopic structure of the muscular oesophagus of Xiphinema]. Boletin de la Real Sociedad Española de Historia Natural, Seccion Biología 64, 177-185 (in Spanish).

Lopez-Abella, D., Jimenez-Millan, F. \& Garcia Hidalgo, F. (1967) Electron microscope studies of some cephalic structures in Xiphinema americanum. Nematologica 13, 283-286.

Navas, A. \& ARIAs, M. (1986) On the distribution and ecology of Xiphinema index and X. italiae in Spain. Nematologia Mediterranea 14, 207-215.

Navas, A., Bello, A. \& Arias, M. (1988) Ecology and potential distribution of Xiphinema diversicaudatum and $X$, pachtaicum in Continental Spain. Nematologica 34 (in press).

PEÑa Iglesias, A. \& AYUso, P. (1971) [Identification of strains of grapevine fanleaf virus as the cause of three grapevine diseases in Spain]. Anales del Instituto Nacional de Investigaciones Agrarias, Protección Vegetal 1, 115-137 (in Spanish).

Peña Iglesias, A., Castro, F., Fresno, J. \& Carazo, G. (1978) [Ultrastructure of herbaceous plants infected by various nepoviruses]. Monografias INIA 18, 103-108 (in Spanish).

REY, J.M., ANDrÉs, M.F. \& ARIAS, M. (1988) A computer method for identifying nematode species. 1. Genus Longidorus. Revue de Nématologie 11, 129-135.

RoCA, F. \& ARIAS, M. (1986) A new Paratrichodorus species from Spain. Nematologia Mediterranea 14, 181185.

Romero, J., Peña Iglesias, A., Fisac, R., Anton, M.T. \& Perez, M.C. (1978) [Comparison of the biological, biophysical and biochemical properties of several strains of grapevine fanleaf virus]. Monografias INIA 18, 1785-1799 (in Spanish).

Romero, J., Carazo, G. \& Peña Iglesias, A. (1985) [Artichoke degeneration. II. New data for the characterization of the causal virus]. Anales del Instituto Nacional de Investigaciones Agrarias, Agricola 28, 97-106 (in Spanish).

SturHaN, D. (1985) [Studies on the Xiphinema coxi complex]. Nematologica 30, 305-323 (in German). 